\title{
From Balkanization to Regional Economic Integration Project: Cefta Agreement
}

\author{
Muharrem Can, Candidate Ph.D
}

Doi:10.5901/jesr.2014.v4n4p414

\author{
muharremcan@hotmail.com.tr
}

\begin{abstract}
The years of the 1990s for Balkan Regions were this era was remembered war, political unrest and collapse of Former Yugoslavia. This means despite of regional economic integration in rest of the World, this region had political unrest, the emergence of new states and economic problems. Between 2002 and 2006, before CEFTA Agreement signed, more than bilateral free trade agreements were signed between these countries. After signing CEFTA in 2006, these agreements that signed before replaced with this agreement. Both bilateral FTAs and after CEFTA agreement has a positive impact on trade volume between the countries in the regional. Although there are some obstacles regional economic integration, especially technical barriers, the countries in the region, have some advantages. Some of these are common language, common border, land areas, cultural similarity, geographical position and historical links.
\end{abstract}

Keywords: Regional Trade Agreements, Balkanization, Bilateral Trade Agreements, Western Balkan countries, CEFTA, Nontechnical barriers.

\section{Introduction}

In our study, we discus Regional Trade Agreements (RTAs) and the reason of the increase number of this kind of agreements in 1990s years. On the other hand, the years of the 1990s for Balkan Regions were this era was remembered war, economic sanction, political unrest and collapse of Former Yugoslavia. From the first years of the 2000s years to 2006, 32 bilateral trade agreements were signed between the countries in the regions. In 2006 Albania, Moldova, Croatia, Bosnia and Herzegovina, Macedonia, Montenegro, Serbia and Kosovo signed Central European Free Trade Agreement (CEFTA).

Beside the Free Trade Agreements (FTAs) and Regional Trade Agreements (RTAs), some factors such as common language, common borders and common history has a positive effect on the trade volume. We analyze export and import data from 2001 to 2012 years, after the Free FTAs and CEFTA agreements, intraregional trade especially export volume increase between the member countries. Although there is a marked progress in regional trade, it is still under the potential. Main obstacles seem to technical barriers and political problem between the countries.

In our study, we argued balkanization concept, RTAs and bilateral trade agreement and the reason of the increasing number of the RTAs in 1990s and after 2000s.

\section{Methodology}

In the study, export and import data from year 2001 to 2012 for 8 Balkan countries has been used. The data has been collected from different sources as; International Trade Center Database, United Nations Commodity Trade Statistics Database, Kosovo Central Bank Statistics, National Bureau of Statistics of the Republic of Moldova, Bosnia and Herzegovina Statistics Agency and Turkish Statistics Institution. As it has been stated the aim of the study is to analyze the effect of trade agreements on trade volumes of countries in the Balkan region.

\section{Regional Trade Agreements}

In accord with article XXIV of the General Agreement on Tariffs and Trade (GATT), there are two forms of preferential agreements' free trade areas, in which member countries eliminate internal barriers to trade and custom unions, in which members also adopt a common external tariff (Bagwell \& Staiger, 1999, p. 218) (Bagwell \& Staiger, 1999, p. 218). In February 1996, World Trade Organization (WTO) realized the important of RTAs and appointed a Committee on Regional Trade Agreements (CRTA) to congruent these agreements (Panagariya, 1999, p. 8) (Panagariya, 1999, p. 8). An important source of concern with PTAs is that they can damage non-members. One direct channel is occurred if the PTAs members divert their import demand away from the non-members and this effect cause of reduce non-members' export prices (Karacaovali B. 2010, p. 2). 
A number of studies PTAs have a 'trade creation' and 'building bloc' or 'trade diversion' and stumbling block effects. Baldwin (1993 and 1995), Ethier (1998), Laird (1999), Clausing (2001), Glick and Rose (2002), Lee et al.(2008) Krugman (1991 and 1993) conceive that PTAs would raise intra bloc trade is outweigh the losses from trade diversion. Emerging of several PTAs would result in inter-bloc trade discrimination and tariff barriers and thus, would injure multilateral corporation and hamper global free trade (Singh 2010, 1546). PTAs are more trade diverting and more likely to be supported by member countries. Each countries firms have some advantages to access partner's market and by diverting trade away from rest of the world (Krishna, 1998, p. 229).

In 2010, 26 new notifications involving 18 regional trade agreements (RTAs) were received by the WTO. 484 RTAs notified to the WTO as of 31 December 2010, 293 were in force. RTAs include bilateral and inter-regional free trade agreements (WTO, 2011a, p. 54) (WTO, 2011a, p. 54). Among the best known are; The EU, The European Free Trade Association (EFTA), The North American Free Trade Agreement (NAFTA), The Southern Common Market (MERCOSUR), The Association of Southeast Asian Nations (ASEAN) Free Trade Area (AFTA), and - The Common Market of Eastern and Southern Africa (COMESA) ${ }^{1}$

According to Lawrence (1996) unlike multilateral trade liberalization, regional arangements promote (especially FTAs) ${ }^{2}$ "deeper" integration. Rather than being confined to "shallow" integration in terms of liberalization of trade among members, they involve "deep" integration through coordination (Panagariya, 1999, p. 43) (Panagariya, 1999, p. 43).

Most of the East Asian countries, especially countries in Northeast Asia, have been well-known to prefer nondiscriminatory multilateral liberal efforts rather than a discriminatory regional liberalization policy. However, after realizing the importance of regional economic cooperation from the East Asian financial crisis in 1997, these countries have changed their policy attitude affecting from global approach to favoring a regional approach (Invonn, 2008, p. 4) (Invonn, 2008, p. 4).

Years of the 1990s, RTAs were increasing worldwide. However in Balkan Region, this is not the case. Indeed, this decade was remembered as disintegration, balkanization even war for Balkan countries. Indeed, during these years, new states emerged in the region.

\section{Balkanization and Cefta}

\subsection{Balkanization}

On every continent, in almost every major nation override political reality is that of increasing social separatism and fermentation-sometimes violent splintering of humanity by ethnic group, race, and religion. The most dramatic change is found in the countries used to be known Yugoslavia and Czechoslovakia. Even in America melting pot racial, ethnic, and other varieties of separatism are distinctly on the rise. Blacks identify themselves as "African American" (Glynn, 1993, s. 21)(Glynn, 1993, s. 21).

It was coined at the end of World War I to describe the ethnic and political fragmentation that followed the breakup of the Ottoman Empire; particularly in the Balkans (the term Balkanization is today invoked to explain the disintegration of some multiethnic states and their devolution into dictatorship, ethnic cleansing, and civil war). Balkanization has occurred in places other than the Balkans, including Africa in the 1950s and '60s, following the dissolution of the British and French colonial empires there. In the early 1990s the disintegration of Yugoslavia and the collapse of the Soviet Union led to the emergence of several new states-many of which were unstable and ethnically mixed-and then to violence between them. The concept of 'Balkanity' as a political and geo-cultural concept should be located within the historical landscape organized by the 1878 Congress in Berlin. The modern history of the Balkans properly begins in the Berlin Congresshome to 'carve-up of the Balkans' (Grubacic, 2012, s. 442)(Grubacic, 2012, s. 442).

Although Balkanization originally referred to Europe's Balkan Peninsula and its historic break-up after control by the Ottoman Empire. The term balkanization itself was coined at the end of World War I following this break-up as well as that of the Austro-Hungarian Empire and the Russian Empire (Grubacic, 2012, s. 443)(Grubacic, 2012, s. 443). It can be said that one meaning of the Balkanization is dismantling of the empires such as ottoman, Austria and Hungarian and emerged some new independent states. This is closest meaning to Balkanization. The ethnical, religious, cultural and even cult, etc. is a social richness and live together in peacefully. It is other meaning of balkanization.

Malcolm traces the migration of Croats, Serbs, Vlachs, Jews, Gypsies, and others who settled in Bosnia over the centuries (Mestrovic, 1996, p. 77)(Mestrovic, 1996, p. 77). Like the Balkans itself, balkanization was a project of inter- 
ethnic coexistence, a transethnic and pluri-cultural space of many diverse worlds (Grubacic, 2012, p. 439)(Grubacic, 2012, p. 439). But, Yugoslavia and Balkan dream of an interethnic, pluri-cultural space-was dramatically dismantled in the 1990s. (Grubacic, 2012, p. 440)(Grubacic, 2012, p. 440). Relatively few authors point to June of 1991, when Serbian forces attacked both Slovenia and Croatia. Branka Magas argues in her 1993 book The Destruction of Yugoslavia that the war actually began with Serbian suppression of the Albanian Muslims in Kosovo in 1989 (Mestrovic, 1996, s. 70)(Mestrovic, 1996, s. 70). In 1993, George Kennan, in the Camegie Endowment reprint, connected the contemporary quest for a Greater Serbia (war of this time) to the previous Balkan wars of 1912-1913 (Mestrovic, 1996, s. 71)(Mestrovic, 1996, s. 71).

There is no convincing reason to assume that the war in the former Yugoslavia has been a religious war, or that the religious factor has been the crucial one in it (Vrcan, 1994, s. 117)(Vrcan, 1994, s. 117). A visible and almost official usage of the current interpretation of national history, on the one side, in terms of a genuine and sacred martyrology (in Serbian ordodoxy) or a Cavary (in Croatian catholicism) or a holocaust (in Bosnian Islam) (Vrcan, 1994, s. 120)(Vrcan, 1994, s. 120). My contention is that the destruction of state-socialist Yugoslavia was a project of the same century-long process of Balkanization from above. In contrast, Socialist Yugoslavia was a result of a long tradition of movements for Balkan unity, a manifestation of Balkanization from below (Grubacic, 2012, p. 43) (Grubacic, 2012, p. 43). In short, the wars in Balkan region in late 80s and 1990s were based on ethnic, religious reason. The wars collapse of the Balkan and ended Balkan dream and peace.

It is no accident that when Yugoslavia collapsed in 1991, the term Balkans came back (Grubacic, 2012, p. 43)(Grubacic, 2012, p. 43). Yugoslavia dissolved in 1990 and its member republics begun the stiff road toward political pluralism and market economy. The first years of 1990s were marked by many political shocks, the military conflict in Croatia, the war in Bosnia and Herzegovina, the UN embargo and NATO intervention in Serbia and the subsequent refugees' crisis. These resulted in a loss of the traditional markets, built physical borders and trade barriers among the republics and loss of the natural trade partners (Petreski M., 2013, p. 29).

\subsection{Bilateral Free Trade Agreements and CEFTA Agreement}

At the beginning of the 21st century for the first time in the history, all the countries in the region have common strategic goals: to provide security, political stability and socio-economic operation was seen as an integral part of the preparation for integration into development to their citizens through a process of becoming members of NATO and the EU (Kušljugić, M., p. 48).

Glikov found that history had discouraged the Balkan countries from engaging in regional trade, thus preventing them from exploiting geographical proximity as a meaning of achieving increasing benefits from intra-regional trade (Delevic, 2007, p. 14). External and internal shock in 1990s in Balkan region (all military economic and political crises) directly affected neighboring countries for example through influxes of refugees' disruptions in transport and trade and loss of investor confidence. Good economic activities started in the region only after 2000 when political changes took place first in Croatia then in Serbia. Trade in export, import and trade have continued since 2000 (Delevic, 2007, p. 48).

Among the activities within the Stability Pact, a Memorandum of Understanding was signed on trade liberalization and facilitation (27 June 2001 in Brussels) (Kapetanović \& Kulundžić, 2009, p. 110). The main obligation of the memorandum was for the countries to start negotiations on bilateral FTAs that should be concluded before the end of 2002 (Krizmanic, 2007, p. 560).

The critical moments in this evolution of ownership came with the establishment of the Stability Pact in 1999 and finally with its transformation to the Regional Cooperation Council (RCC) between 2006 and 2008 (Kušljugić , p.93). The Stability Pact designed a two-stage trade liberalization process. During the first stage, the SEE countries were to remove administrative barriers, suspend the introduction of new trade barriers and reduce all trade barriers in a coordinated way. During the second stage, the SEE countries would join the WTO and establish a free trade area (Balic \& Zdravkovic, 2009, p. 101).

In June 2001, the auspices of the Stability Pack for SEE, a MoU was signed on trade liberalization and facilitation to development of a new work of bilateral trade agreements and to dismantle of regional non-tariff barriers (Delevic, 2007, p. 56).

The activities already developed within the Stability Pact in addition to the initiatives from the region, served as a basis to enlarge the scope of regional co-operation with the Thessaloniki Agenda of 2003, which is considered as another important benchmark of the process of EU integration of the Western Balkans. While remaining in the context of reconciliation together with enhancing regional co-operation, the targets and areas for regional co-operation became much more ambitious (Jordanova, 2009, p. 66). As part of this, the Stability Pact designed a two-stage trade liberalization 
process. During the first stage, the SEE countries were to remove administrative barriers, suspend the introduction of new trade barriers and reduce all trade barriers in a coordinated way. During the second stage, the SEE countries would join the WTO and establish a free trade area (Balic \& Zdravkovic, 2009, p. 101). The bilateral versus multilateral approach from the outset, and especially since the Thessaloniki EU Summit in 2003. Conflict between the bilateral and multilateral approaches and its impact on regional co-operation is elaborated in detail (Kušljugić, M. p. 50).

After 2002 till 2006 before CEFTA agreement, more than 30 bilateral FTAs were signed between the countries in the region.

Table 1: Bilateral FTAs between the CEFTA Countries

\begin{tabular}{|c|c|c|c|c|c|c|c|c|}
\hline & & & & & & & & SAA agreements with the EU \\
\hline & 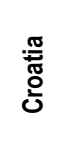 & 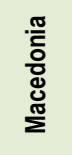 & 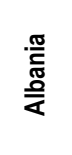 & 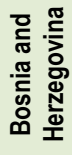 & 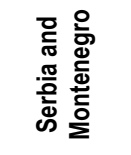 & 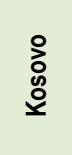 & 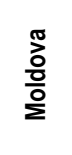 & \\
\hline Croatia & & 2002 & 2003 & 2005 & 2004 & 2006 & 2004 & 01.03 .2002 \\
\hline Macedonia & 2002 & 2002 & 2002 & 2002 & 2006 & 2006 & 2005 & 01.06 .2001 \\
\hline Albania & 2003 & 2003 & 2002 & 2004 & 2004 & 2003 & 2004 & 01.12 .2006 \\
\hline Bosnia and Herzegovina & 2005 & 2005 & 2002 & 2004 & 2002 & 2006 & 2004 & 01.07.2008 \\
\hline Serbia and Montenegro & 2004 & 2004 & 2006 & 2004 & 2002 & 2004 & 2004 & 01.02.2010 \\
\hline \multicolumn{3}{|l|}{ Montenegro (as of 2008} & & & 01.01.2008 & & & 01.01 .2008 \\
\hline Kosovo & 2006 & 2006 & \multicolumn{2}{|c|}{2006} & 2003 & 2006 & & - \\
\hline Moldova & 2004 & 2004 & 2005 & 2004 & 2004 & 2004 & & - \\
\hline
\end{tabular}

Source: (Petreski M 2013..5).

These FTAs result in free trade to the signatories, although not completely liberalized, has established free trade area for almost all industrial products and some agricultural products. (Krizmanic, 2007, p. 560)(Krizmanic, 2007, p. 560). But it is not enough for deep economic integration.

By the end of the 2004, a key report of the SP 'Working table II' stated that there was a consensus that a multilateral free trade agreement would greatly contribute the economic efficiency of the liberalization process. It should be the geographic expansion of the CEFTA agreement or the evaluation of the existing network of bilateral free trade agreement into a new multilateral agreement (Dangerfield, 2006, p. 320) (Dangerfield, 2006, p. 320).

CEFTA agreement is defines a unified free trade area in WBC. This agreement was initially formed among the Central European Countries, the countries co-called Vizagrad Group: Poland, Hungary and Czechoslovakia (later Czech Republic and Slovakia). This agreement was signed on December 21, 1992 in Poland and took effect in July 1994. In the second round, Slovenia (1996), Bulgaria (1996), Romania (1997), Croatia (2003) and Macedonia (2006) joined to this agreement (Jelisavac\&Zirojevic, 2009, p. 118).

The new agreement, called CEFTA 2006, was started on November 9, 2006 in Brussels and signed on December 19, 2006, at the SEE Prime Minister's meeting in Bucharest. The agreement was approved on March 31, 2007, and finally went into effect on July 26, 2007 (Jelisavac\&Zirojevic, 2009, p. 118) for Albania, Macedonia, Moldova, Montenegro and UNMIK Kosovo, for Croatia it entered to force on 22 August, for Serbia on 24 October and for Bosnia and Herzegovina on 22 November 2007. Full implementation and application CEFTA 2006 started at the end of the 2007 (Druziç, Penava, \&Sekur, 2009, p. 102). After signing and implementation these FTAs, almost all custom duties of industrial products and some agricultural products were eliminated.

\subsection{Trade Liberalization and Its Effect on Trade Volume}

There are a number of extra conditioning variables that affect trade other than multilateral trade liberalization. There are many extraneous factors such as culture (e.g., whether a pair of countries share a common language), geography (whether none, one, or both are landlocked), and history (Rose A. K., 2004, p. 99). Probably these factors affected positively on intra CEFTA trade volume. But trade liberalization (especially FTAs) is the key factor that effect trade volume between the countries in the region. 


\subsection{Import Share of the Intra CEFTA}

As we accept the year of the 2001 as a base year (as a 100), the increase rate is 315.7 in 2006. In these years, more than 30 bilateral trade agreements were signed. It should de say that these agreements result in positive effect on the trade increase but modest. The share of the import rate of the intra CEFTA is 12\% in 2001 and $10.2 \%$ in 2006 .

After CEFTA agreement signing in 2006, the year of the 2006 is decided as the base year; in 2012 the increase rate is 163 . From 2007 to 2012 share of the intra CEFTA is almost the same, $11,9 \%$ and $12.4 \%$ respectively.

Table 2: Import Share of the Intra CEFTA

\begin{tabular}{|l|c|c|c|c|c|c|}
\hline \multicolumn{1}{|c|}{ Years } & $\mathbf{2 0 0 1}$ & $\mathbf{2 0 0 2}$ & $\mathbf{2 0 0 3}$ & $\mathbf{2 0 0 4}$ & $\mathbf{2 0 0 5}$ & $\mathbf{2 0 0 6}$ \\
\hline Intra CEFTA/Total (\%) & 12 & 13.1 & 8.7 & 10 & 9.1 & 10.2 \\
\hline Index (2001 intra CEFTA=100) & 100 & 127.9 & 120.9 & 190 & 231.8 & 315.7 \\
\hline Years & $\mathbf{2 0 0 7}$ & $\mathbf{2 0 0 8}$ & $\mathbf{2 0 0 9}$ & $\mathbf{2 0 1 0}$ & $\mathbf{2 0 1 1}$ & $\mathbf{2 0 1 2}$ \\
\hline Intra CEFTA/total (\%) & 11.9 & 11.5 & 12.1 & 12.8 & 12.6 & 12.4 \\
\hline Index (2006 intra CEFTA=100) & 157 & 185.9 & 138.7 & 150.6 & 176 & 163 \\
\hline
\end{tabular}

Source: our calculation, data taken from International Trade Center Database, United Nations Commodity Trade Statistics Database, Kosovo Central Bank Statistics, National Bureau of Statistics of the Republic of Moldova, Turkish Statistical Institution, Bosnia and Herzegovina Ministry Statistics Agency.

\subsection{Export Share of the Intra CEFTA}

As we accept the year of the 2001 as a base year (as a 100), the increase rate in 2006 is $453.9 \%$. these years, as I stated above, more than 30 bilateral trade agreements were signed. It should say that these agreements result in positive effect on the trade increase, and this effect is more than import effect. The share of the export rate of the intra CEFTA is $15,9 \%$ in 2001 and $26.4 \%$ in 2006 . It is a fairly good growth if compare import rate of the same years.

After CEFTA agreement signing in 2006, this year is decided as the base year; in 2012 the increase rate is 150 . But in 2009 the index is 113 which is the lowest. This is probably because of global economic crises. On the other hand, from 2007 to 2012 share of the CEFTA are $30 \%$ and $27.1 \%$.

Table 3: Export Share of the Intra CEFTA

\begin{tabular}{|l|c|c|c|c|c|c|}
\hline Years & 2001 & 2002 & 2003 & 2004 & 2005 & 2006 \\
\hline Intra CEFTA/total (\%) & 14.5 & 24 & 24.1 & 15.8 & 23.2 & 24.4 \\
\hline Index Intra CEFTA (2001=100) & 100.0 & 164.8 & 165.9 & 108.6 & 159.8 & 167.8 \\
\hline Years & 2007 & 2008 & 2009 & 2010 & 2011 & 2012 \\
\hline Intra CEFTA/total (\%) & 28.0 & 27.9 & 29.2 & 26.1 & 25.0 & 24.6 \\
\hline Index (Intra CEFTA 2006=100) & 115 & 114 & 120 & 107 & 102 & 101 \\
\hline
\end{tabular}

Source: our calculation, data taken from International Trade Center Database, United Nations Commodity Trade Statistics Database, Kosovo Central Bank Statistics Department, National Bureau of Statistics of the Republic of Moldova, Turkish Statistical Institution, Bosnia and Herzegovina Ministry Statistics Agency.

Generally, from beginning of the 2000s to 2012, intra CEFTA trade share increased. Still this is not enough. Due to the lack of the energy sources and lack of the high- teck industries, countries in the region are dependent on import. Export similarities and political problem are the other two problems, but main problem is non-tariff barriers.

\subsection{Technical Regulations and Non-Tariff Barriers}

The main obstacle to implementation of CEFTA 2006 is non-tariff barriers (Jelisavac \& Zirojevic, 2009, p. 120). Apart from removing custom duties, CEFTA also implies the removal of non-tariff barriers (co-operation on technical obstacles to trade, standards, sanitary and phytosanitary measures, co-operation of customs and other cross-border authorities, etc.), liberalization of public procurements, etc (Kapetanović \& Kulundžić, 2009, p. 110). In practice, the most prevalent 
measures with which Companies reported to face difficulties are: product characteristic requirements $(70 \%)$, labeling and/or packaging requirements $(67 \%)$, testing, inspection and quarantine requirements $(60 \%)$, traceability requirements (origin, processing history) (Margaf, October 8, 2009, p.11). Companies per party that faced partly difficulties regarding testing, inspectional quarantine requirements by the countries are Bosnia and Herzegovina (98.2\%), Macedonia (74.1\%), Serbia (71.7\%), Montenegro (61,9\%), Albania (40,5) and Kosovo (27 \%) (Margaf, October 8, 2009, p. 14)(Margaf, October 8, 2009, p. 14).

The agreement establishes to eliminate non-tariff barriers through the work three subcommittees: subcommittee for non-tariff and technical barriers, subcommittee for the cooperation of customs organs, including rule of the origin and subcommittee for agriculture, including sanitary and phytosanitary measures (Jelisavac\&Zirojevic, 2009, p,120). These subcommittees such as the Sub-Committee on TBTs and NTBs and the Joint Committee are the appropriate forum to identity and agree on actions that can be undertaken to reduce and eliminate NTBs on the multilateral and pluriliteral level (OECD, 2009, p. 4).

\section{Conlusion}

The scientific innovation part of the study lay in two folds; theoretical and practical bases. The theoretical base represented with rich and deep literature review of world scholars, while the practical part represented by means of analyses of the trade agreements on trade volumes in the Balkan region. 1990s years for Balkan region mean war, disintegration, and embargo and new states. However, number of the RTAs increased every region in the world.

Beginning of the 2000s, some regional initiatives were launched. These initiatives aimed economic integration and political stability for the region. Thus from 2002 to 2006 more than 30 FTAs were signed. In 2006 a regional trade agreement was signed that is CEFTA agreement was replaced with FTAs. Both FTAs and CEFTA agreements have a positive effect on the trade volume between CEFTA countries. Still trade volume and economic integrating are not completed yet. But coming years, economic integrations will take place more deeply.

\section{References}

(2012). Statistics Year Book of Republic Moldova. Chişinãu: Moldovo Statitic Instituion.

Bagwell, K., \& Staiger, R. W. (1999). An Economic Theory of GATT. The America Economic Review, 215-249.

Balic, V., \& Zdravkovic, M. (2009). CEFTA 2006-Limit and Opportunity. Regional Cooperation and economic Integration, (P.101-117).

Dangerfield, M. (2006). Subregional Integration and EU Enlargemen; Whre next for CEFTA. JCMS 2006, 44(2), 305-325.

Delevic, M. (2007). Regional Cooperation in the Western Balkans. Paris: European Union, Institute for Security Studies.

Druzic, I., Penava, M., \& Sekur, T. (2009). Dynamics and Compozition of Trade Relations between Crotia and CEFTA 2006 Countries. Regional Cooperation and Economic Integration, Challenges and opportunuties , (p. 101 115). Skopje.

Frey, H. W. (1995). Immigration and Internal Migration 'Flight' from US Metropolitan Areas:Toward a New Demographic Balkanisation. Urban Studies, 32(4-5), 733-757.

Glynn, p. (1993, July). the Age of Balkanization. Commentary, 21-24.

Grubacic, A. (2012). Balkanization of Politics, Politics of Balkanization. Globalizations, 9(3), 439-449. http://data.un.org/Data.aspx? $q=$ export+bosnia\&d=ComTrade\&f=_11Code\%3a1\%3brtCode\%3a70. (n.d.). Retrieved 04 29, 2014, from http://data.un.org. http://www.bqk-kos.org/?cid=1,121. (n.d.). Retrieved 3 12, 2014, from http://www.bqk-kos.org/. http://www.wto.org/english/docs _e/legal_e/04-wto.pdf. (n.d.). Retrieved 8 8, 2013, from Agreement Establishing the Agreement of Word Trade Organizatoin.

Invonn, P. (2008). Proliferating Regional Trade Agreements in East Asia:Why and Whither?

Jelisavac, S., \& Zirojevic, M. (2009). CEFTA 2006 and Economic Crises-Case of Serbia. regional Cooperation and economic Integration, (pp. 117-125).

Jordanova, M. R. (2009). Regional Cooperation in the Balkans 1996-2008 - from Imposed to Intrinsic. In Dialogues, Ownership for Regional Cooperation in the Western Balkan Countries (pp. 53-79). Frederich-Ebert-Stiftung.

Jovancevic, R. (2009). The Impact of World Economic Crisis On the Sustainable Growth of the South-Eastern European Countries: Does Regional Cooperation matter?

Kapetanović, A., \& Kulundžić, Z. (2009). The New Initiative - a New Paradigm? Prospect of a New Balkan Regionalism. The New Initiative for an Old Problem. In Dialogues, Ownership for Regional Cooperation in the Western Balkan Countries (pp. 79-93). Frederich-Ebert-Shiftung.

Krishna, P. (1998). Reg'onalism and Multilateralism; A Political Economy Approach. The Quartely Journal of Economics, 113(1), 227251.

Krizmanic, M. (2007). The New CEFTA with Special Reference to its Infl uence on Accession. In T. (. Capera, Croatian Yearbook of European Law and Policy (pp. 559-581). zagreb: Faculty of Law, University of Zagreb.

Kušljugić. (n.d.). Development of Regional Cooperation in the Western, Balkans and EU Integration - Evaluation of Regional Cooperation Initiatives. In Dialogues, Ownership for Regional Cooperation in the Western Balkan Countries (pp. 47-53). 
Frederich-Ebert-Stiftung.

Margaf, B. (October 8, 2009). Key Findings of regional business survey on NTBs. Round Table on reducing Non tariff Barriers to trade in CEFTA Parties. Budepest: GTZ.

Mestrovic, S. G. (1996, November). The Balkanization of the Balkans. Society, 34(1), 70-80.

Odnoso, B. i. (2010). Sarajevo: Trgovinski Aspekti Sporazuma o Stabilizaciji i Pridruzivanju.

Panagariya, A. (1999). The Regionalism Debate:An Overwiev. The World Economy, 22(4), 455-476.

Petreski, M. (2013). Southeastern European Trade Analysis: A Role for Endogenous CEFTA-2006? Emerging Markets Finance and Trade, 49(5), 26-44.

Rose, A. K. (2004). Do We Really Know That the WTO Increases Trade? The American Economic Review, 94(1), 98-114.

Singh, T. (2010). Does International Trade Cause Economic Growth A Survey. the World Economy.

TUIK. (2014, 04 01). www.tuik.gov.tr.

WTO. (2011a). World Trade Report 2011, The WTO and preferential trade agreements: From co-existence to coherence. WTO.

WTO. (n.d.). www.wto.org. Retrieved 1 16, 2014, from http://www.wto.org/english/tratop_e/region_e/region_e.htm

www.trademap.org/tradestat/Bilateral_TS.aspx. (n.d.). Retrieved 4 12, 2014, from www.trademap.org. 